Romuald Grzybowski

(Gdańsk)

\title{
Odradzanie się harcerstwa polskiego po 1956 r. i próby włączenia go w struktury systemu wychowawczego szkoły
}

\section{Okoliczności i warunki odrodzenia się ruchu harcerskiego w Polsce w 1956 r.}

Likwidacja resztek pluralizmu wśród organizacji młodzieżowych w Polsce w 1948 r. wpłynęła także na dalsze losy Związku Harcerstwa Polskiego (ZHP). Formalnie ZHP nie został objęty przymusową akcją zjednoczeniową ruchu młodzieżowego z 1948 r., w wyniku której na zjeździe we Wrocławiu, w dniu 22 lipca, cztery ówczesne organizacje młodzieżowe: Związek Walki Młodych (ZWM), Związek Młodzieży Wiejskiej RP „Wici”, Organizacja Młodzieży Towarzystwa Uniwersytetu Robotniczego (OMTUR) oraz Związek Młodzieży Demokratycznej (ZMD) zostały połączone (,zjednoczyły się") w jedną organizację pod nazwą Związek Młodzieży Polskiej (ZMP) ${ }^{1}$. Stworzenie monolitycznej, ideologicznej organizacji młodzieżowej przez rządzącą partię komunistyczną było zapowiedzią nieuchronnych ataków pod adresem ZHP, niemieszczącego się we właściwym dla państwa totalitarnego schemacie relacji: partia - związek młodzieżowy. Tak też się stało. Pretekstem działań wymierzonych przeciwko ZHP stały się m.in. zarzuty, że tempo przemian ideowych w łonie tej organizacji nie dorównuje wzrostowi aktywności politycznej ZMP we wszystkich obszarach życia społecznego. Władze komunistyczne oceniały w związku $\mathrm{z}$ tym, że powstała „dość istotna rozbieżność między programem wychowawczym dwóch organizacji, $\mathrm{z}$ których jedna działała wśród dzieci w szkołach podstawowych, druga wśród młodzieży w szkołach średnich"”2. W rezultacie, po dwóch latach od powstania ZMP, na szczeblu władz centralnych podjęto decyzję o faktycznej likwidacji ZHP i przekształceniu go w Organizację Harcerską ZMP (OH ZMP) ${ }^{3}$.

Oceniając z perspektywy lat tę decyzję władz komunistycznych trudno uznać ją za zaskakującą. W latach ofensywy ideologicznej, politycznej i gospodarczej, jaką kierowana przez B. Bieruta partia podjęła - na wzór innych państw bloku komunistycznego - na terenie Polski, nie mogła ostać się organizacja młodzieżowa bazująca na wywiedzionych ze skautingu i międzywojennej tradycji harcerstwa polskiego ideałach służby Bogu, Pol-

\footnotetext{
${ }^{1}$ A. Garlicki, Historia 1939-1996/97. Polska i świat, Warszawa 1997, s. 207.

${ }^{2}$ B. Hillebrandt, Polskie organizacje młodzieżowe XIX i XX wieku. Zarys historyczmy, Warszawa 1986, s. 378 .

${ }^{3}$ Ibidem, s. 378.
} 
sce i bliźnim oraz braterstwie $\mathrm{z}$ innymi ludźmi ${ }^{4}$. Akt włączenia ZHP w struktury ZMP w sferze wychowawczej zaowocował $\mathrm{m}$.in. wprowadzeniem nowych, obcych treści ideowych do wychowania harcerskiego. Towarzyszyło temu radykalne odcinanie się OH ZMP od dotychczasowej tradycji i doświadczeń ZHP oraz wypróbowanych metod i form wychowania. Rezultatem tych działań była widoczna nawet dla kierownictwa PZPR utrata przez OH ZMP ducha inicjatywy oraz bierność jej członków.

W sierpniu 1956 r., w trakcie obrad III Plenum Zarządu Głównego ZMP, omówiono także problem harcerstwa. Krytyczna ocena działalności $\mathrm{OH} \mathrm{ZMP,} \mathrm{a} \mathrm{także} \mathrm{próba} \mathrm{uprze-}$ dzenia wydarzeń, jakie zapowiadała „odwilż polityczna” postępująca w całym bloku państw komunistycznych, skłoniły kierownictwo ZMP do ustępstw wobec harcerstwa. Wyrazem tego była decyzja wspomnianego Plenum ZG ZMP o powrocie do niektórych tradycyjnych metod pracy harcerstwa $w$ procesie socjalistycznego wychowania młodzieży. Zgoda władz partyjnych na poszerzenie zakresu autonomii harcerstwa zaowocowała utworzeniem w ramach ZMP Organizacji Harcerskiej Polski Ludowej (OH PL) ${ }^{5}$. Kolejnym krokiem była decyzja o formalnym usamodzielnieniu harcerstwa. Nastąpiło to 9 listopada 1956 r., podczas Narady Komendantów Wojewódzkich OHPL ${ }^{6}$. W praktyce oznaczało to zaledwie wyprowadzenie harcerstwa ze struktur tracącego grunt pod nogami $\mathrm{ZMP}^{7}$. Istotę i charakter OH PL określała przyjęta w trakcie wspomnianej narady deklaracja, w myśl której miała być ona masową, patriotyczną, świecką organizacją dzieci, młodzieży i instruktorów, działającą pod ideowym przywództwem PZPR. Co istotne, kierownictwo OH PL wykazywało ograniczoną otwartość w stosunku do dawnych działaczy harcerskich, deklarując gotowość do współpracy z nimi w nowej organizacji, jeśli będą gotowi zaakceptować przedstawione we wspomnianej deklaracji warunki polityczne ${ }^{8}$.

Dalsze wydarzenia na tym etapie dziejów ZHP, w szczególnej atmosferze ,polskiego października" 1956 r., potoczyły się niezwykle szybko. Wbrew przewidywaniom kierownictwa OH PL nie mógł odbyć się w przewidzianym terminie zjazd tej organizacji, za to 8 grudnia 1956 r. zwołano do Łodzi Krajową Naradę Działaczy Harcerskich. W trakcie jej obrad do delegatów OH dołączyła grupa dawnych działaczy ZHP. W wyniku tego, obradujące gremium przekształciło się w I Zjazd Związku Harcerstwa Polskiego w Polsce Ludowej ${ }^{9}$. Zjazd podjął uchwałę o przywróceniu powstającemu ZHP obrzędowości harcerskiej sprzed 1949 r., w tym symboli harcerskich w postaci krzyża harcerskiego i lilijki. Jednakże działacze harcerscy, wywodzący się z OH PL, działając w duchu polityki PZPR, przeciwstawili się reaktywowaniu ZHP, to znaczy przywróceniu jego dawnej ideologii i oblicza ideowego. W rezultacie - jak stwierdza B. Hillebrandt - utworzony

\footnotetext{
${ }^{4}$ J. Balon, Harcerstwo, w: Encyklopedia pedagogiczna XXI wieku, t. II, Warszawa 2003, s. 153.

${ }^{5}$ B. Hillebrandt, op.cit., s. 379.

${ }^{6}$ Tbidem, s. 379.

${ }^{7} \mathrm{Z}$ perspektywy dzisiejszej wiedzy o omawianym okresie można postawić tezę, że poprzez formalne usamodzielnienie OH PL władze komunistyczne za wszelką cenę chciały utrzymać przy życiu organizację w kształcie przez siebie stworzonym, posłuszną poleceniom partii, realizującą jej program ideologiczny i polityczny w odniesieniu do dzieci i młodzieży.

${ }^{8}$ B. Hillebrandt, op.cit., s. 379.

${ }^{9}$ Ibidem, s. 379.
} 
w grudniu 1956 r. „Związek Harcerstwa Polskiego był w rzeczywistości nowym związkiem, w sensie kadrowym i programowym nawiazującym do tradycji poprzedzających go organizacji ZHP i OH PL"10. Wspomniany Zjazd ZHP wyłonił naczelne władze ZHP: Naczelną Radę Harcerską i Główną Kwaterę Harcerstwa. Przewodniczącym Naczelnej Rady Harcerskiej został niezwykle zasłużony dla harcerstwa polskiego Aleksander Kamiński. Natomiast naczelnikiem Głównej Kwatery Harcerstwa została wybrana działaczka OH PL - Zofia Zakrzewska.

\section{Polityczne i ideologiczne konteksty odbudowy programowej harcerstwa}

Podjęte decyzje kadrowe zmierzały do tego, aby pomieścić w nowym ZHP dwie zróżnicowane ideowo i politycznie grupy działaczy $\mathrm{i}$ instruktorów - o orientacji chrześcijańsko-narodowej i orientacji komunistycznej. Konstrukcja ta musiała prowadzić do nieuchronnych konfliktów i napięć we władzach naczelnych ZHP. Były one nieuniknione m.in. dlatego, że nowe kierownictwo PZPR z Władysławem Gomułką na czele nie zamierzało rezygnować $\mathrm{z}$ dominującego wpływu na treść $\mathrm{i}$ formy wychowania młodego pokolenia Polaków. Nieobojętne zatem dla władz komunistycznych było to, co działo się w organizacjach młodzieżowych w Polsce po 1956 r. Wskazywała na to m.in. przyjęta na omawianym I Zjeździe ZHP deklaracja ideowa głosząca, że „ZHP skupia młodzież i instruktorów do wspólnej pracy dla Polski Ludowej, pracuje pod ideowym kierownictwem PZPR, wychowuje swych członków w duchu idei socjalizmu i jest organizacją świecką""1.

Zjazd ZHP z 1956 r. nie wypracował jednak dalekosiężnego programu działania. Miała go kształtować zróżnicowana ideowo i politycznie kadra instruktorska Związku. Ta jednak - jak pokazała praktyka - szybko się spolaryzowała. Instruktorzy ZHP z lat Drugiej Rzeczypospolitej w rzeczywistości nie zaakceptowali ideowo-politycznego podporządkowania swojej organizacji partii komunistycznej. Ich opór budziła zwłaszcza kwestia ideowego przywództwa PZPR i świeckość organizacji. Wspomniany już Aleksander Kamiński opowiadał się na przykład za uznaniem kierowniczej roli PZPR w państwie, ale sprzeciwial się wdrażaniu ideologii komunistycznej $\mathrm{w}$ harcerstwie. Potwierdzeniem rosnącego nacisku partii na harcerstwo były decyzje dotyczące treści prawa harcerskiego: w brzmieniu z 1957 r. przyjęto, że harcerz służy Polsce (bez dodawania: Ludowej), ale już w kwietniu 1958 r. odrzucono apolityczność ZHP ${ }^{12}$.

Wątpliwości budziła także problematyka programowo-metodyczna, sprowadzająca się do odpowiedzi na pytanie o zakres zaangażowania ZHP w dzieło wychowania socjalistycznego dzieci i młodzieży. $Z$ tym $\mathrm{z}$ kolei wiązała się kwestia dostosowania do nowych zadań metodyki harcerskiej. Sprawą sporną było wskazanie źródeł ideału wychowawczego harcerstwa. Działacze harcerscy z lat Drugiej Rzeczypospolitej uważali, że zgodnie z założeniami ustroju demokratycznego powinien on wyrastać z uogólnionych

\footnotetext{
${ }^{10}$ Ibidem, s. 379.

${ }^{11}$ Ibidem, s. 380 .

${ }^{12}$ Z. J. Hirsz, Historia polityczna Polski 1939-1993, Białystok 1996, s. 282.
} 
dążeń różnych grup społecznych, $\mathrm{z}$ tradycji, historii i ukształtowanego na przestrzeni wieków, osadzonego w tradycji chrześcijańskiej systemu wartości społeczeństwa polskiego $^{13}$. Natomiast instruktorzy wywodzący się z OH PL opowiadali się za wyprowadzaniem ideału wychowawczego harcerstwa $\mathrm{z}$ ideologii socjalizmu ${ }^{14}$. Rosnący nacisk kierownictwa partii na ideologiczne i polityczne podporządkowanie ZHP doprowadził do tego, że część instruktorów przedwojennego harcerstwa odeszła ze związku. Potwierdzeniem rozłamu w ZHP była uchwała centralnego zespołu partyjnego w ZHP, zatytułowana "Za i przeciw”, w której jej autorzy - partyjni harcerze - opowiedzieli się za „harcerstwem jako ruchem społecznym, a przeciwko uczynieniu go terenem wolnej gry sił; za ideałem człowieka o jednym morale, a przeciwko rozdzielaniu wychowania moralnego od wychowania ideowego; za patriotyzmem, a przeciwko racjonalizmowi i mitowi braterstwa skautowego; za twórczym rozwijaniem metod harcerskich, a przeciwko dogmatyzmowi metodycznemu i generalnej rewizji metod harcerskich"15.

Okres względnego pluralizmu w ZHP w okresie PRL nie trwał zatem długo. W trakcie obrad Naczelnej Rady Harcerskiej w dniach 21-23 kwietnia 1958 r. dokonano zmian w tymczasowym statucie ZHP. W ich wyniku zlikwidowano Prezydium NRH, w którym skupiali się zwolennicy powrotu do korzeni harcerstwa z okresu międzywojennego, a przynajmniej sprzed 1948 r. Kompetencje dotychczasowego Prezydium powierzono Głównej Kwaterze Harcerstwa. W ten sposób partia odzyskała wpływ na gremia kierownicze $\mathrm{ZHP}^{16}$. Dopełnieniem działań zmierzających do pełnej kontroli partii nad działalnością ZHP było powołanie w kwietniu 1958 r. Rady Głównej Przyjaciół Harcerstwa, złożonej z ówczesnych działaczy partyjnych i państwowych. Jej pierwszym przewodniczącym został członek Biura Politycznego KC PZPR, minister obrony narodowej, generał Marian Spychalski ${ }^{17}$.

Stworzony w 1958 r. system podwójnej kontroli partii nad ZHP dowodzi, że komuniści traktowali ZHP bardzo poważnie. Mieli też wobec niego własne plany. Potwierdzeniem tego były działania dostosowujące harcerstwo do potrzeb programu partii, podjęte na Walnym Zjeździe ZHP w dniach 18-21 kwietnia 1959 r. w Warszawie ${ }^{18}$. Staranna selekcja kandydatów na zjazd dała spodziewany przez partię efekt: w dyskusji nad zmianami w statucie, dotyczącymi m.in. ideowego przywództwa PZPR oraz wychowania młodzieży w duchu socjalizmu, tylko jeden $\mathrm{z}$ uczestników zaprezentował stanowisko

\footnotetext{
${ }^{13}$ R. Grzybowski, Przemiany historyczne ideałów wychowawczych, w: Zagadnienia celów edukacyjnych, praca zbiorowa pod red. J. Rutkowiak, Gdańsk 1987, s. 26-53.

${ }^{14}$ B. Hillebrandt, op.cit., s. 381.

${ }^{15}$ B. Hillebrandt, Ewolucja ideowa ZHP w Polsce Ludowej, „Z dziejów Ruchu Mlodzieźowego" 1984, nr 8, s. 104-105. Cyt. za: Z.J. Hirsz, op.cit., s. 282.

${ }^{16} \mathrm{~W}$ języku .ówczesnych władz komunistycznych w ten sposób „przezwyciężono konserwatywne tendencja w kierownictwie ZHP". Por. B. Hillebrandt, Polskie organizacje..., s. 381.

${ }^{17}$ Drugim przewodniczącym RGPH, w latach 1971-1985, był inny członek BP KC PZPR, przewodniczący Rady Państwa - Henryk Jabłoński.

${ }^{18}$ Przemówienie do delegatów wygłosił ówczesny I sekretarz KC PZPR, Władysław Gomułka. Zapowiedział w nim włączenie harcerstwa w nurt komunistycznego wychowania dzieci i młodzieży. W związku z tym postawił przed ZHP zadanie wychowania przyszłych współgospodarzy i współtwórców „socjalistycznej ojczyzny".
} 
nawiązujące do poglądów zwolenników restytuowania ZHP w jego pierwotnej formule ideowej. Nic zatem dziwnego, że wspomniane zmiany w statucie ZHP przegłosowano przygniatającą większością głosów.

II Zjazd zamknął okres ostrej walki o oblicze ideowe ZHP. Można przyjąć, że losy harcerstwa polskiego, próbującego odrodzić się po nocy stalinowskiej stanowiły dobrą ilustrację rzeczywistych intencji nowego kierownictwa PZPR, z Władysławem Gomułką na czele. Należy przypomnieć, że po wydarzeniach polskiego października $1956 \mathrm{r}$. założenia ustrojowe PRL nie zostały znacząco zmodyfikowane ${ }^{19}$. Jak twierdzi Andrzej Garlicki, praktyka przełomu lat 50. i 60. XX wieku pokazała dobitnie, że formułowane w 1956 r. społeczne programy i nadzieje nigdy nie były programem Gomułki ${ }^{20}$. Uważał on bowiem, że system komunistyczny, budowany w Polsce jest dobry, należy tylko usunąć jego wynaturzenia, takie jak stalinowski terror. Był natomiast przekonany o potrzebie pozostawienia innych elementów tzw. państwa socjalistycznego. Wśród wielu działań stabilizujących ramy tego systemu znalazły się posunięcia dotyczące dalszych kierunków rozwoju ruchu młodzieżowego w Polsce. W styczniu 1957 r. powstrzymano w związku z tym spontaniczny rozwój organizacji młodzieżowych, łącząc Rewolucyjny Związek Młodzieży i Związek Młodzieży Robotniczej w Związek Młodzieży Socjalistycznej ${ }^{21}$.

Jednym z najważniejszych celów działania komunistów w latach 1957-1960 było bowiem przywrócenie wpływu na młodzież. Potwierdził to Gomułka w trakcie obrad zorganizowanej w dniu 24 września 1958 r. narady ,aktywu oświatowego". Wskazał on na niezmienność celów socjalistycznego wychowania dzieci i młodzieży. Także w tym obszarze potępił jedynie metody ich urzeczywistniania. Otwarcie też zaatakował Episkopat Polski za „,naruszanie świeckości szkoły”22. Przyczyną niepokoju kierownictwa partii stał się proces systematycznego rozszerzania wpływów Kościoła na młodzież. Wyrazem tego był rosnący udział młodzieży w ruchu pielgrzymkowym na Jasną Górę. Stąd też uchwała IX Plenum KC PZPR z maja 1957 r. stawiała przed partią zadanie ,opieki nad młodzieżą" i odbudowę politycznego ruchu młodzieży. Poszczególne organizacje partyjne zostały zobowiązane do podjęcia na swoim terenie działalności wychowawczej. W uzasadnieniu stwierdzano, że „różne siły wsteczne i reakcyjne usiłują zamącić świadomość młodzieży obcą ideologią, nacjonalizmem i klerykalizmem, niewiarą w wyższość socjalizmu i jego przyszłość”23. W omawianej uchwale partia ponownie atakowała Kościół katolicki, zarzu-

\footnotetext{
${ }^{19}$ R. Grzybowski, Przelomy polityczne jako momenty zwrotne $w$ polityce oświatowej PRL, w: Oświata, wychowanie $i$ kultura fizyczna w rzeczywistości spoleczno-politycznej Polski Ludowej (1945-1989). Rozprawy $i$ szkice, pod red. R. Grzybowskiego, Torun 2004, s. 52-54.

${ }^{20}$ A. Garlicki, op.cit., s. $282-290$.

${ }^{21}$ Zjazd zalożycielski nowej organizacji odbył się w dniach 25-27 kwietnia 1957 r.. Do ZMS przeszła większość czlonków skompromitowanego w latach stalinowskich, rozwiązanego w styczniu 1957 r., ZMP.

${ }^{22}$ A. Gładysz, Oświata - kultura - nauka w latach 1947-1959. Węzłowe problemy polityczne, Warszawa - Kraków 1981, s.46.

${ }^{23}$ Uchwała LX Plenum KC PZPR z maja 1957 roku, w: Programy oświatowe polskiej radykalnej lewicy socjalistycznej i polityka oświatowa PZPR, wybór K. Dobrzyński, Warszawa 1982, s. $206-207$.
} 
cając duchowieństwu szerzenie nietolerancji wobec niewierzących i brak obywatelskiej postawy $^{24}$.

\section{Próby włączenia harcerstwa w struktury systemu wychowawczego zreformowanej szkoły}

W zaistniałych warunkach nadzieje przedwojennych instruktorów na niezależność odradzającego się ZHP nie mogły się ziścić. Pięcioletni okres między II a III Zjazdem ZHP (w kwietniu 1964 r.) to lata wbudowywania tej organizacji w struktury tworzonego przez partię jednolitego systemu oddziaływania ideologicznego na młodzież. W związku $\mathrm{z}$ tym, na początku lat 60 . kierownictwo PZPR za priorytetowe zadanie uznało włączenie się ZHP w nurt działalności ideowo-wychowawczej szkoły. Naczelną dyrektywę w tej sprawie przyniosła uchwała VII Plenum KC ze stycznia 1961 r., w której określono zadania państwa w zakresie przebudowy szkolnictwa oraz rewizji działania całego systemu oświaty i wychowania ${ }^{25}$. Projektowana reforma ustroju szkolnego miała wygenerować szkołę ogólnokształcącą, która byłaby w stanie „wychowywać ludzi światłych, [...] oddanych sprawie socjalizmu, identyfikujących własne dążenia i cele z potrzebami i celami społeczeństwa budującego socjalizm, [...] przepojonych duchem internacjonalizmu, braterskiej solidarności z krajami obozu socjalizmu"26.

Realizacja wspomnianych zadań wymagała - w przeświadczeniu kierownictwa partii - włączenia ZHP w nurt działalności wychowawczej szkoły. Stąd też juź w pierwszych miesiącach 1961 r. Wydział Nauki i Oświaty KC PZPR rozpoczął prace mające na celu „Zacieśnienie więzi ZHP ze szkołą”27. Odpowiadając na wyraźnie wyartykułowane zapotrzebowanie polityczne pracownicy wspomnianego wydziału sformułowali tezę, w myśl której „działalność ZHP winna być integralną częścią programu wychowawczego szkoły. ZHP powinien czynnie uczestniczyć tak w kształtowaniu socjalistycznych postaw młodzieży, jak i w rozwiązywaniu aktualnych szeroko pojętych zadań wynikających $\mathrm{z}$ planu dydaktyczno-wychowawczego szkoły"28. Tymczasem - jak stwierdzali z pewnym zdzi-

\footnotetext{
${ }^{24}$ Okazją do podjęcia kolejnej wielkiej ofensywy przeciwko Kościołowi - jedynej już w tym okresie struktury społecznej zdolnej przeciwstawić się władzy komunistycznej - była przypadająca w 1966 r. rocznica Tysiąclecia Chrztu Polski - Millennium polskie. Rozpoczętemu przez Kościół w 1957 r. programowi Wielkiej Nowenny Tysiąclecia, którego istotną częścią miała być wędrówka pobłogosławionej przez papieża kopii obrazu Matki Boskiej Częstochowskiej po diecezjach i parafiach, władze komunistyczne przeciwstawiły akcję Budowy „1000 szkół na tysiąclecie”. Koordynacją działań centralnych władz państwowych w okresie Millennium zajmowała się Komisja Partyjno-Rządowa ds. Tysiąclecia. Por. Z Archiwum Akt Nowych. Millennium polskie. Walka o rzqd dusz, praca zbiorowa, Warszawa 2002.

${ }^{25}$ Por. Uchwała VII Plenum KC PZPR z dnia 21 stycznia 1961 roku, w: Źródła do dziejów wychowania i myśli pedagogicznej, t. III, wybór S. Wołoszyn, Warszawa 1966, s. 729-738.

${ }^{26}$ Ibidem, s. 732.

${ }^{27}$ Archiwum Akt Nowych w Warszawie, Akta Wydziału Nauki i Oświaty KC PZPR [dalej: AAN, KCPZPR], Uwagi do notatki Głównej Kwatery Harcerstwa „W sprawie zadań harcerstwa na terenie szkoły”, sygn. 237/XVI - 297.

${ }^{28}$ Ibidem, s. 2.
} 
wieniem przedstawiciele KC PZPR - dotąd ZHP zdecydowanie odrzucał wszelkie sugestie o konieczności zacieśnienia więzi organizacyjnej ze szkołą.

Taką postawę zarówno kierownictwa ZHP, jak i całego „aktywu” harcerskiego thumaczono sobie różnie. Wskazywano $\mathrm{z}$ jednej strony na obawy instruktorów przed powtórzeniem błędów $\mathrm{OH}$ ZMP, z drugiej zaś - na elitarny charakter harcerstwa, obejmującego wąskie kręgi dzieci i młodzieży, i to głównie w miastach. Przytaczano też inny argument, jakoby wśród działaczy harcerskich dominował pogląd o przytłaczającym wpływie szkoły na młodzież, z racji jej obowiązkowego charakteru i powszechności. W rezultacie program działania ZHP - jak oceniali pracownicy wspomnianego wydziału - zmierzał do odrywania jego członków od szkoły.

Warto podkreślić, że sprzeciw wobec tezy o potrzebie zacieśniania więzi harcerstwa ze szkołą zgłaszała Główna Kwatera Harcerstwa, grupująca instruktorów aprobujących ścisłe podporządkowanie ZHP partii. Jak podkreślano w sprawozdaniach Wydziału Nauki i Oświaty, na tym tle powstawały niejednokrotnie konflikty między kierownictwem GKH a jej wydziałami i niektórymi komendami chorągwi ${ }^{29}$. Oceniając tę sytuacje przedstawiciele KC PZPR doszli do wniosku, że w kierownictwie GKH nie została przezwyciężona tradycja dawnego harcerstwa, opartego na założeniach skautingu i realizowanego w nim ideału, „człowieka zaradnego w życiu, porządnego i lojalnego obywatela". System ten - jak podkreślano - absolutyzował zainteresowania dzieci, ale kształtował tylko te, które służyły jej ideałowi ${ }^{30}$. Dlatego - konkludowano - ZHP dystansował się od pracy w szkole i nie stanowił dotąd wartościowego elementu realizowanego w niej systemu wychowawczego. Inną przyczyną braku zaangażowania ZHP w działalność wychowawczą szkoły była - zdaniem pracowników Wydziału Nauki i Oświaty KC PZPR - powierzchowna i jednoznacznie negatywna ocena pracy OH ZMP z lat 1950-1956. Eksponując błędy i wypaczenia przekreślono cały dorobek $\mathrm{OH}$. Tymczasem, w opinii aparatu partyjnego, $\mathrm{OH}$ wniosła do organizacji „,socjalistyczne treści wychowania, wprowadziła organizacje dzieci do szkół wiejskich i działała w ścisłej więzi ze szkołą i nauczycielami"31.

Zająwszy takie stanowisko kierownictwo PZPR nie przyjmowało argumentacji Głównej Kwatery Harcerstwa, zgodnie z którym szkoła jest ważnym ogniwem w systemie socjalistycznego wychowania, ale nie głównym. Obok niej na wychowanie wpływa wiele innych ważnych czynników i środowisk, jak dom rodzinny, podwórko, ulica itp. Zdaniem Głównej Kwatery Harcerstwa te właśnie środowiska powinny stanowić teren działalności harcerskiej, to bowiem ZHP powinno tworzyć front wychowawczy dla ich kształtowania $^{32}$. Pogląd przedstawicieli harcerstwa mówiący o prymacie zainteresowań wśród motywów wyboru i udziału dzieci i młodzieży w działalności ZHP partia oceniała jako błędny. Pracownicy aparatu dowodzili w związku z tym, że ,ideowo-wychowawcza organizacja

\footnotetext{
${ }^{29}$ AAN KC PZPR, Notatka o rozwoju ZHP i potrzebie pracy na terenie szkoły z dnia 2 marca 1961 roku, sygn. 237/XVI - 297.

${ }^{30}$ Ibidem, s. 27.

${ }^{31}$ Ibidem, s. 28.

${ }^{32}$ Ibidem, s. 28.
} 
młodzieży nie może ograniczać swej działalności do zaspokajania zainteresowań członków, ale musi kształtować je w kierunku socjalistycznym"33.

Równie negatywnie oceniano koncentrację ZHP na akcji letniej. W opinii przedstawicieli aparatu administracyjnego partii, takie podejście skutkowało odrywaniem młodzieży od nauki szkolnej, co negatywnie wpływało na wyniki działalności dydaktyczno-wychowawczej szkoły. Dowodem na „kampanijność stylu pracy drużyn harcerskich” miała być mała aktywność drużyn harcerskich, wzrastająca tylko w okresie przygotowania do akcji letniej. Świadczyć to miało o braku takich tematów pracy, które by utrzymywały stały, wysoki poziom intensywności pracy drużyn harcerskich. Na poparcie tej tezy przytaczano dane wskazujące na malejącą atrakcyjność ZHP w kręgach dzieci i młodzieży. Wynikało z nich, że na przestrzeni roku szkolnego 1960/61, a więc już po II Zjeździe ZHP, z organizacji tej wystąpiło 62500 zuchów i harcerzy oraz rozwiązało się 915 drużyn. Rocznie występowało z ZHP około $1 / 5$ jej członków; zaledwie $31,5 \%$ dzieci i młodzieży posiadało staż organizacyjny dłuższy niż 2 lata. Jak podkreślano, wśród występujących z ZHP dominowały dzieci i młodzieź pozostająca w szkole (statystyki zawierały też młodzież niepodejmującą dalszej nauki po ukończeniu szkoły podstawowej) $)^{34}$. Oczywiście, oceniając powyższe dane z perspektywy dzisiejszego stanu badań nie sposób nie zauważyć, że przyczyn malejącego zainteresowania młodzieży harcerstwem należało doszukiwać się przede wszystkim w jego ponownej, radykalnej ideologizacji po II Zjeździe ZHP. Rozczarowanie dzieci i młodzieży, dawnych instruktorów, a zapewne i rodziców, co do celów i zadań odbudowywanego po 1956 r. ZHP znajdowało wyraz przede wszystkim w postaci decyzji o opuszczeniu jego szeregów.

Takiej interpretacji kierownictwo partii nie zamierzało jednak przyjąć. Eksponowało za to korzyści, płynące z podporządkowania harcerstwa socjalistycznej szkole. Jedną z nich była dostępność bazy szkolnej dla drużyn harcerskich. Należy stwierdzić, że w omawianym okresie problem bazy dla rozwijającego się ZHP niewątpliwie istniał. Drużyny harcerskie poświęcały mu wiele wysiłku i energii, organizując własne stanice, kluby, wydawnictwa itd. O pomoc w tej sprawie zwracały się też do władz państwowych. Te jednak na początku lat 60 . XX w. przyjęły tezę, że „na własną bazę materialną może pozwolić sobie [tylko] organizacja o charakterze elitarnym" "35. Ponieważ ZHP w omawianym okresie z założenia miał być organizacją nie tyle elitarną, co masową, powinien zdaniem KC PZPR - wykorzystywać bazę placówek oświatowo-wychowawczych, głównie w postaci 3000 świetlic szkolnych oraz placówek wychowania pozaszkolnego. Ogniskując w nich swą działalność ZHP miał przyczyniać się do ich umacniania i „przekształcania w lubiane przez młodzież ośrodki ideowego, kulturowego i naukowego oddziaływania"36.

Obecność ZHP w szkołach, tak pożądana przez kierownictwo PZPR, napotkała jednak na początku lat 60 . XX w. nieprzewidziane przeszkody. Jedną z nich było wejście do

\footnotetext{
${ }^{33}$ AAN KC PZPR, Uwagi do notatki Głównej Kwatery Harcerstwa „W sprawie zadań harcerstwa na terenie szkoły", sygn. $237 / \mathrm{XVI}-297$, s. 9.

${ }^{34}$ Ibidem, s. 6.

${ }^{35}$ Ibidem, s. 7.

${ }^{36}$ Ibidem, s. 7.
} 
szkół średnich Związku Młodzieży Socjalistycznej (ZMS), utworzonego - jak już o wspomniano - w roku 1957 na gruzach dawnego ZMP. Zrodziło to, jak oceniał Wydział Nauki i Oświaty KC PZPR, niezdrową rywalizację między nim a ZHP. Dotyczyło to przede wszystkim działaczy harcerskich umocowanych w strukturach szkół średnich, którzy zmierzali wręcz do wyparcia z ich murów $\mathrm{ZMS}^{37}$. Temu celowi podporządkowana została też aktywność Głównej Kwatery Harcerstwa, koncentrującej cały wysiłek na programowaniu pracy drużyn starszoharcerskich kosztem drużyn w szkołach podstawowych. Trzeba przyznać, że sytuacja szkół średnich w tym okresie była nietypowa; $\mathrm{z}$ danych ZHP wynikało bowiem, że niemal połowa harcerzy szkół średnich była jednocześnie członkami ZMS. Władze oświatowe, a zwłaszcza Wydział Nauki i Oświaty KC PZPR, u progu 1961 r. nie negowały konieczności istnienia samodzielnych drużyn starszoharcerskich. Postulowały jednak zmianę ich profilu tak, by ich członkami byli głównie funkcyjni harcerscy - zastępowi i przyboczni. Miałoby to rozwiązać problem kadr dla drużyn młodszych ${ }^{38}$.

Zagadnienie podwójnej przynależności młodzieży szkół średnich do ZHP i ZMS, jak również podział sfer wpływów poszczególnych związków młodzieżowych w szkole stało się $\mathrm{w}$ pierwszej połowie lat 60. przedmiotem ostrego sporu pomiędzy kierownictwem wspomnianych związków. Jak w wielu innych sprawach, głos decydujący w tej kwestii należał do Komitetu Centralnego, a przede wszystkim do przywoływanego tu wielokrotnie Wydziału Nauki i Oświaty. Rozwiązania przyjęte przez KC PZPR w przededniu III Zjazdu ZHP w kwietniu 1964 r. w niewielkim tylko stopniu uwzględniały postulaty Głównej Kwatery Harcerstwa.

Przedstawiciele KC PZPR, zamiast spodziewanego rozdziału obszarów oddziaływania ZHP i ZMS, postulowali zacieśnienie współpracy między nimi, a także ze Związkiem Młodzieży Wiejskiej (ZMW) na terenie szkół średnich ${ }^{39}$. Miała się ona odbywać „,z poszanowaniem samodzielności, zwyczajów i planów tychże organizacji"40. Wszakże warunkiem tej harmonijnej współpracy miało być zaangażowanie ZHP w realizację zadań szkoły, zapisanych w jej planie pracy wychowawczej. Bardzo pożądane w odczuciu władz partyjnych było też podjęcie współpracy przez ZHP ze szkolnymi kołami przyjaciół Związku Radzieckiego, spółdzielczością uczniowską, szkolnymi kołami krajoznawczo-turystycznymi, kołami PCK i Ligi Przyjaciół Żołnierza ${ }^{41}$. Władze partyjne zamierzały również włączyć harcerstwo w nurt pracy placówek wychowania pozaszkolnego. Zadaniem harcerzy miało być przekazywanie organizatorom pracy ideowo-wychowawczej $w$ tych placówkach doświadczeń harcerzy $w$ zakresie rozwijania i popularyzowania wśród dzieci i młodzieży idei działalności społecznej. Placówki wy-

\footnotetext{
${ }^{37}$ Ibidem, s. 7.

${ }^{38}$ Ibidem, s. 7.

${ }^{39}$ Problemy podwójnej przynależności młodzieży szkół średnich, jak również podziału obszarów działania w obrębie szkoły podstawowej i średniej stały się przedmiotem zainteresowania Wydziału Nauki i Oświaty KC, a także Głównej Kwatery Harcerstwa w roku 1963, w związku z przygotowaniami do III Krajowego Zjazdu ZHP (3-5 kwietnia 1964 r.) Szerzej zostaną one omówione w odrębnym opracowaniu.

${ }^{40}$ AAN, KC PZPR, Tezy w sprawie pracy ZHP w szkołach, sygn. 237/XVI - 297, s. 17.

${ }^{41}$ Ibidem, s. 15 .
} 
chowania pozaszkolnego miały natomiast przyczynić się do rozwiązania problemów lokalowych harcerstwa przez udostępnienie mu części swoich pomieszczeń.

Katalog ,szkolnych zadan”" harcerstwa przygotowany przez władze partyjne u progu lat 60. XX w. na tym się jednak nie kończył. Zgodnie z postanowieniem KC PZPR, głównym zadaniem szkolnych organizacji ZHP, ZMS i ZMW miało bowiem być kształtowanie świadomej, aktywnej postawy młodzieży szkolnej wobec nauki i obowiązków uczniowskich $^{42}$. Oznaczało to, że ZHP powinien aktywnie współuczestniczyć w wytwarzaniu atmosfery aprobaty i moralnego uznania dla uczniów odnoszących się z odpowiedzialnością do swych szkolnych obowiązków. Harcerze mieli też zwalczać przejawy lekceważącego stosunku niektórych uczniów do nauki i pracy, do szkoły i nauczyciela ${ }^{43}$. Przed ZHP postawiono ponadto zadanie walki z drugorocznością w szkołach. Zakładano, że drużyny starszoharcerskie będą organizowały punkty pomocy w nauce dla dzieci członków drużyn młodszoharcerskich. Płaszczyzną rozwoju tej formy działalności ZHP miała być „harcerska służba dziecku". Przewidywano też, że harcerze, którzy mimo pomocy starszych koleżanek i kolegów nie zlikwidują ocen niedostatecznych i zostaną zmuszeni do powtarzania klasy, zostaną odsunięci na jakiś czas od pracy $w$ drużynie ${ }^{44}$. Zadanie wdrażania uczniów do sumiennej nauki łączono z jednym z kluczowych haseł ideologii komunistycznej, jakim było kształtowanie u nich ,socjalistycznego stosunku do pracy". ZHP miało także wspierać pracę szkoły poprzez upowszechnianie wśród swoich członków i uczniów wiedzy o współczesnym świecie i wprowadzanie młodzieży w mechanizmy życia społeczno-gospodarczego ludzi dorosłych.

Najbardziej jednak władzom partyjnym zależało na włączeniu ZHP w proces realizacji sztandarowego hasła pedagogiki komunistycznej, jakim było kształtowanie naukowego światopoglądu dzieci i młodzieży. Zadanie to, uznawane przez KC PZPR za jeden z najważniejszych celów działania zreformowanej w 1961 r. szkoły polskiej, pozostawało $\mathrm{w}$ jaskrawej sprzeczności $\mathrm{z}$ leżącymi u podstaw dawnego ZHP ideami służby Bogu, Polsce i bliźnim. Próba uczynienia z harcerstwa instytucji krzewiącej ateizm wśród swych członków mogła być dla wielu instruktorów ostatecznym argumentem przemawiającym za opuszczeniem jej szeregów. Kierownictwo PZPR zdawało sobie $\mathrm{z}$ tego $\mathrm{z}$ pewnością sprawę, ale nie zamierzało się $\mathrm{z}$ tego postulatu wycofać. Uznało bowiem, że ZHP ma w swym ręku różne formy i metody wychowania, bardziej przemawiające do wyobraźni młodego człowieka niż lekcja, podręcznik czy literatura. Wymagało to, jak podkreślano w materiałach Wydziału Nauki i Oświaty KC PZPR, „opracowania sensownego programu pracy przede wszystkim z kadrą instruktorską"45. Dalsza dyskusja w samym harcerstwie miała zatem koncentrować się nie na narzuconych mu ideałach i celach wychowania, lecz na sposobach ich skutecznej realizacji ${ }^{46}$.

\footnotetext{
${ }^{42}$ Ibidem, s. 18.

${ }^{43}$ Ibidem, s. 17.

${ }^{44}$ Ibidem, s. 17 .

${ }^{45}$ Ibidem, s. 21.

${ }^{46}$ B. Hillebrandt, Polskie organizacje..., s. 382.
} 
Nakreśliwszy dla ZHP nowy, obszerny katalog zadań wynikających z założenia o nadrzędnej roli szkoły $w$ stosunku do innych instytucji uczestniczących w procesie wychowania młodego pokolenia Polaków, władze komunistyczne zadekretowały też dalszy szybki rozwój ilościowy harcerstwa ${ }^{47}$. Zgodnie $\mathrm{z}$ zasadami gospodarki planowej, postawiły przed ZHP konkretne cele $\mathrm{w}$ zakresie pozyskiwania nowych członków. Za błędną uznano przy tym tezę, że nie wszyscy uczniowie mają zainteresowania społeczno-polityczne. Partia - jak stwierdzono w wytycznych Wydziału Nauki i Oświaty - odrzuciła ją wraz z wywiedzionym ze skautingu ideałem ,porządnego człowieka,48. Dyrektywa KC PZPR była jednoznaczna: „[...] trzeba konsekwentnie zdążać do tego, by ZHP stał się ideowo-wychowawczą masową organizacją uczniów"49. Trzeba przyznać, że ofensywa partii przyniosła w tym zakresie wymierne rezultaty: w końcu 1963 r. stan liczebny ZHP przekroczył 1 milion członków. Na III Zjeździe sformułowano w związku z tym hasło: „Kierunek - dwa miliony”50. Okolicznością sprzyjającą realizacji tego założenia była łagodna $\mathrm{z}$ pozoru forma wdrażania $\mathrm{w}$ życie narzuconych harcerstwu zadań wychowania ideologicznego dzieci i młodzieży. Przykładowo, w roku 1964 program wychowawczy ZHP miał przekazywać młodzieży wskazówki na temat tego, jak żyć. Pozostawiało to instruktorom dużo swobody w podejściu do problematyki ideologicznej i politycznej ${ }^{51}$.

Zarysowane tu prawidłowości procesu odradzania się ZHP po okresie stalinowskim wskazują, że - $\mathrm{z}$ małymi wyjątkami - przebiegał on wedhug założeń i planów działania PZPR, realizowanych po $1956 \mathrm{r}$. w nowej formule. ZHP okazał się przy tym wyjątkowo atrakcyjny i ważny dla partii, która po krótkim okresie zamieszania spowodowanego wydarzeniami polskiego października 1956 r., na przełomie lat 50. i 60 . XX w. postanowiła za wszelką cenę przywrócić swój dominujący wpływ na młodzież. W praktyce oznaczało to ponowną dominację PZPR nad wszystkimi organizacjami i związkami młodzieżowymi w Polsce. Wytyczając cele ideologicznej indoktrynacji dzieci i młodzieży polskiej partia postanowiła uczynić z ZHP pierwsze ogniwo systemu ideologicznej obróbki młodego pokolenia. Co szczególnie istotne, komuniści postanowili wkomponować harcerstwo w struktury systemu szkolnego, uczynić je narzędziem pracy ideowo-politycznej zreformowanej w $1961 \mathrm{r}$. szkoły polskiej, bazującej na wdrażanej z żelazną konsekwencją zasadzie świeckości i laickości procesów nauczania i wychowania dzieci i młodzieży. Pozostaje otwartą kwestia oceny, w jakim stopniu zamierzenia te udało się zrealizować. Odpowiedź na to pytanie wymaga dalszych badan $\mathrm{z}$ użyciem innych metod badawczych.

\footnotetext{
${ }^{47}$ Szkole miała być podporządkowana nie tylko drużyna harcerska, ale też rodzina $\mathrm{i}$ inne instytucje społeczne uczestniczące $\mathrm{w}$ procesie wychowania młodego pokolenia.

${ }^{48}$ AAN, KC PZPR, Tezy w sprawie pracy ZHP w szkołach, sygn. 237/XVI-297, s. 21.

${ }^{49}$ Ibidem, s. 22.

${ }^{50}$ B. Hillebrandt, Polskie organizacje ..., s. 382.

${ }^{51}$ Z. J. Hirsz, op.cit., s. 282.
} 


\title{
The Revival of the Polish Scouting Movement after 1956 and Attempts to Incorporate it in the Structures of the School's Educational System
}

\begin{abstract}
Summary
The Polish scouting movement, which wrote such a beautiful page of history during the Second World War, after 1945 found itself in an extremely difficult situation. The aims and the forms of educational influence of ZHP (pol. abbr. Zwiazzek Harcerstwa Polskiego - Polish Scouting Association) proved unacceptable by the government of a totalitarian state, which the Polish People's Republic (Polska Rzeczpospolita Ludowa - PRL) was. As a result, ZHP was originally marginalized, and then, for several years, had been completely dissolved. The reconstruction of the scouting movement started at the end of 1956 , on the wave of a political thaw. Such actions led, in the years 1956-1958, to a formal recreation of $\mathrm{ZHP}$, however, since then, this organization was entirely subject to PZPR (Polish communist party). Consequently, following 1958, ZHP was incorporated into the structure of a communist youth movement in Poland. Moreover, in accordance with the rules of the socialist political system and the principles of a planned economy, the scouting movement was ,delegated" to work in school. Since then, in compliance with the guidelines of the Central Committee of PZPR, the activity of the Polish Scouting Association (ZHP) was to become an integral element of the school's educational programme. It meant that the scouting movement was supposed to actively participate in shaping of socialist attitudes in children and youth, according to the main task of the Polish school which was reformed in 1961. Unexpectedly, the party authorities and educational authorities were confronted with the opposition of ZHP leadership that they controlled. ZHP, for a long time, resolutely rejected the suggestion about a necessity to strengthen the ties of this organization and school. In reality, in early $1960 \mathrm{~s}$, the scouting movement defended the remnants of its autonomy, struggling against becoming one of the tools for shaping a young generation of Poles through ideologized Polish school. The practice showed that the arguments of scouts did not have any significance for communist authorities as they consequently kept on achieving their own goals.
\end{abstract}

